\title{
Introduction - Language Planning: Where have we been? Where might we be going?
}

\section{Introdução - Planejamento linguístico: Onde estivemos? Para onde poderíamos ir?}

Richard B. Baldauf Jr.*

The University of Queensland

Brisbane / Austrália

ABSTRACT: This paper provides a brief overview of the development and state of language policy and planning and examines some of the directions that language planners have been taking to engage with issues of importance to their discipline. The papers in this volume of RBLA are linked to the overview and the directions being taken by scholars in the field.

KEYWORDS: language planning, language policy, history, future directions, theoretical frameworks, review.

RESUMO: Este artigo apresenta um panorama do desenvolvimento e do estado da área de políticas e planejamento linguístico e examina algumas das direções que seus praticantes têm tomado para engajar-se com questōes relevantespara sua disciplina. Os artigos deste volume daRBLA são vinculados com tal panorama e com as direções tomadas pelos pesquisadores da área.

PALAVRAS-CHAVE: planejamento linguístico, políticas linguísticas, história, diraçōes futuras, quadros teóricos, revisão.

\section{Introduction}

Language planning and policy is a relatively new disciplinary addition to the academy, coming into existence as it did in the years immediately following World War II. However, its philosophical and practical roots in the West go back to the Napoleonic era in France and the need for a single language to manage the army (WRIGHT, 2012) and to end of the $19^{\text {th }}$ and beginning of the $20^{\text {th }}$ century when linguistic scholars were searching for

* r.baldauf@uq.edu.au 
conceptual tools to help them to understand and legitimate the birth of nation states (GAL; IRVING, 1995). That intellectual project was seen to be of great practical significance, underpinning as it did the myth of one nation / one language - something that still influences language planning at a national level today (KAPLAN; BALDAUF, in press).

Leaving aside the central focus on language teaching and learning, Grabe and Kaplan (1991) have describe language planning as the quintessential example of applied linguistics, combining as it does the need for theoretical understandings about language and a requirement for application to real life situations. The discipline of language planning has been defined as systematic, future-oriented change in language code (corpus planning), use (status planning), learning and speaking (language-in-education planning) and/or language promotion (prestige planning) undertaken by some authoritative organisation - most frequently by governments, but increasingly by other organisations - with some community of speakers (see BALDAUF, 2005; KAPLAN; BALDAUF, 2003; RUBIN; JERNUDD, 1971). The discipline itself differentiates between language policy (i.e., the plan - the laws, regulations, rules and pronouncements or statements of intent - these may be substantive or symbolic) and language planning (i.e., the implementation how plans are put into practice) although these terms are quite often used interchangeably in the literature.

\section{Disciplinary history}

Much of the impetus for early language planning studies and for the development of the discipline, initially called language engineering, came from the breakup of European colonial empires after World War II leading to the emergence of new nations in Africa, South and South East Asia and to the need for national languages under the one nation - one language model (See, e.g. KAPLAN, 2003; NEKVAPIL, 2011; RICENTO, 2000). The Ford Foundation - a US philanthropic organisation - undertook early language planning work in East Africa (FOX, 1975; also WHITELEY, 1974 for Kenya) as a surrogate for US interests, and early work also occurred in South and Southeast Asia (e.g., FISHMAN, 1974). The Foundation also supported the Center for Applied Linguistics (Washington, DC), which along with the British Council has contributed to English language development activities in a number of countries where English was seen as a resource that so-called developing polities could use to develop their human capital and bring about 
fuller lives for their people (KAPLAN, 2010). In a recent example, Hamid (2011) discusses of some current practices being used to support 'English for Everyone' in Bangladesh. The French through la francophonie (e.g., DJITÉ, 1990) a grouping of former French colonies, and the lusophone speaking nations - in 1989 through The International Institute of Portuguese Language (SILVA; GUNNEWIEK, 1992) - also have engaged in international language-related human capital development activities. Such educationallyfocused language teaching activities are another type of language planning activity that continues unabated, by the polities just mentioned as well as the Chinese, Germans, Italians, Japanese and Spanish, among others, all vying for linguistic influence.

As the titles of classical language planning volumes attest (See, e.g., COBARRUBIAS; FISHMAN, 1983; FISHMAN, 1974; FISHMAN; FERGUSON; Das GUPTA, 1968; RUBIN; JERNUDD, 1971), the field was seen as strongly linked to development, modernisation and progress, with the implicit notion that was widely reflected in the social sciences of that era (1960s and 1970s) that (language) change, would lead to desired political and social transformations for the betterment of a society (i.e., through a more unified sociocultural system, a reduction in socioeconomic inequality, and access to educational opportunity). In hindsight, the optimism about and faith in development, modernisation, and progress by those involved in bringing about changes to the linguistic system is striking (KAPLAN; BALDAUF, in press).

While the focus in the early classical period was on language planning in new post-colonial nations and the language structuralism of the time, by the 1970s it had become apparent that language planning was not unique to so called developing polities but was relevant to macro problems and situations more generally, and language policy and planning begin to be applied in developed polities, particularly to issues related to migration and linguistic minorities (TOLLEFSON, 2006). However, at the same time there was growing doubt about the efficacy of the positivistic economic and social science paradigms that had dominated the three post-World War II decades, and by the 1980s with the advent of critical sociolinguistics there was widespread disillusionment with directions in the field (See, e.g., BLOOMAERT, 1996; WILLIAMS, 1992). In the $21^{\text {st }}$ century, a new world order, postmodernism and linguistic human rights have created new and broader contexts for the discipline (see RICENTO, 2000 and NEKVAPIL, 2011 for an historical overview) leading to a revival in interest as those involved in language planning 
have confronted issues such as language ecology (e.g., KAPLAN; BALDAUF, 1997; MÜHLHAUSLER, 2000), language rights (e.g., MAY, 2001; 2005), and the place of English and languages other than English in a globalizing world (e.g., PENNYCOOK, 1998; LOW; HASHIM, 2012; MAURAIS; MORRIS, 2003).

\section{Envisioning of the field}

These developments and the increased interest in this field have given rise to a number of recent efforts to define the discipline, the most recent of which is Spolsky's (2012a) The Cambridge Handbook of Language Policy, although key journals like Current Issues in Language Planning, Language Policy and Language Problems \& Language Planning also contribute to that definition. A section on language planning regularly appears in handbooks on applied linguistics (e.g., KAPLAN, 2010; SPOLSKY; HULT, 2008) and in volumes of the Annual Review of Applied Linguistics. For those who are interested in approaches and methods (KAMWANGAMALU, 2011) or in creating or using frameworks to try to understand the field, it can be argued that there are probably four basic approaches that scholars have used to try to draw together aspects of the theoretical literature as a basis for research, these being: a classical, a language management, a domain, or a critical approach. Each of these is briefly explained in the paragraphs that follow. However, there is still general agreement that more needs to be done to provide adequate theorization for a framework for language policy and planning studies.

The original, classical approach to language planning with its roots in modernism was initially developed around Haugen's (1983) four-step model synthesis of the literature that drew on other classical theoretical work referred to previously. This approach has been re-developed in particular by Kaplan and Baldauf (1997, and more fully in 2003; BALDAUF, 2005) to include more recent developments in the field. ${ }^{1}$ Their eight-fold framework (See APPENDIX A) includes productive goals related to status planning (about society) (van ELS, 2005), corpus planning (about language) (HAUGEN, 1983), language-in-education planning (about learning) (COOPER, 1989) and the receptive goal prestige planning (about image) (AGER, 2005). These

\footnotetext{
${ }^{1}$ Also see Hornberger's (2006) model which has been developed independently along parallel lines.
} 
occur at different levels ranging from the macro to the meso to the micro (CHUA;BALDAUF, 2011) and may occur in ways which are overt (explicit) or covert (implicit) (BALDAUF, 1984; EGGINTON, 2010). Furthermore, the issue of agency (i.e., the actors, who is it that is involved) increasingly is seen to be centrally important (BALDAUF, 1982; COOPER, 1989; ZHAO, 2011; ZHAO; BALDAUF, 2012).

The language management approach is said to be a broadly founded general theory which goes beyond linguistics to sociocultural and sociolinguistic issues and which developed almost in parallel with the classical approach - the foundational reference being the Jernudd and Neustupný (1987) article related to language planning in Québec. Nekvapil (2011, p. 880881) explains language management as dealing with "management of utterances (communicative acts)" and that this "takes place in concrete interactions (conversations) of individuals or in institutions of varying complexity...." Simple management occurs at the micro level, while organised management deals with macro issues. The process of language management occurs when deviations from norms are noted, evaluated (positively or negatively), and then an adjustment may occur and may be implemented. Language management theory is very situation oriented, but does not limit itself to language problems as these are seen as a point of departure for studying a variety of language situations (See, ALI, HAMID; MONI, 2011; NEKVAPIL; SHERMAN, 2009; NEUSTUPNÝ; NEKVAPIL, 2003).

The domain approach draws on Fishman's (1972) initial sociolinguistic definition and has been championed by Bernard Spolsky (e.g. 2004; 2009; SHOHAMY, 2006), although he has also been a key figure in bringing the field together through his editorial projects (e.g., SPOLSKY 2012a), and has not used this term explicitly to describe his work (cf. SPOLSKY, 2012b), preferring to use language policy (and language management) as the umbrella term to describe the field. Among the language policy domains and their components (practice, ideology and management) that Spolsky (2009) has suggested are important for language policy are the family (SPOLSKY, 2012b), religion (PAULSTON; WATT, 2012), the workplace (DUCHÊNE; HELLER, 2012), public space (SHOHAMY; GÖRTER, 2009), the school; courts, hospitals and police stations, and the military.

Tollefson (2006) has described critical approaches to language planning as being a critical reaction to the hegemonic approaches found in classical language planning (PHILLIPSON, 1982; 2012). For example, in Africa 
efforts to replace colonial languages with indigenous languages have not been successful because policy makers have privately subverted public policy (KAMWANGAMALU, 2004; MAKONI et al., 2012). Tollefson indicates a second focus exists with research aimed at social change to reduce various types of inequalities. Key ideas from critical theory that inform this approach include: power, struggle, colonization, hegemony and ideology and resistance. The focus of critical study tends to be on critiquing rather than on planning, but two critical approaches that have been used include the historicalstructural approach and governmentality. As an example of the former, Tollefson (1991) examines the essentially political nature of language policy domination and exploitation by the state in a number of contexts, while Li (2011) has used critical discourse analysis in a recent study to examine the shaping of socialist ideology through language policy for primary schools in the PRC, and Skerritt (2012) has used this approach to examine the language planning situation in Estonia. In the governmentality approach, the focus shifts to indirect acts of governing where "researchers examine the techniques and practices of politicians, bureaucrats, educators and other state officials at the micro level, as well as the rationales and strategies they adopt." (TOLLEFSON, 2006, p. 49-50; Also see MOORE, 2002; PENNYCOOK, 2002 for examples of such analyses).

While space is too limited here to provide a more substantial overview of the field, it is hoped that this brief summary whets the reader's appetite for this topic and helps to set the context for where those interested in language policy and planning might be going with their research. Of course, predicting the future is always dangerous, and those who do so are almost always wrong, but the following are some issues that from my perspective will dominate future research in language planning (Also see, BALDAUF; NGUYEN, 2012, for the Asia Pacific region; KAPLAN; BALDAUF, in press).

\section{Where might we be going?}

Just as at the beginning of the last century there was a focus on language and the birth of nation states, language planning in the current century increasingly is dominated by issues related to internationalisation and globalisation. What are the key issues that the four approaches to language policy and planning are trying to address from their varying perspectives as the field enters the second decade of the $21^{\text {st }}$ century? In the paragraphs that follow six key issues are suggested as directions language planning is taking, these 
being: migration and the treatment of new minorities, re-emerging polities and the emergence of supra-states, deconstructing monolingual identities, micro language planning, agency and language power, and medium of instruction.

Internationalization and globalisation have been powerful factors in the language planning related to migration and the treatment of new minorities as note previously by Tollefson (2006). Migration is one of the main reasons for the increase in the learning of languages, especially global languages like English. Some migration is purposeful often related to economics (e.g., Turks in Germany; Indonesian maids in Malaysia) or to matters of the heart (e.g. Vietnamese and Taiwanese women marrying Korean men), while in many other cases migration is created by internal and external displacement when individuals become refugees. Language-in-education planning has become an important part of providing language resources suitable for this mass movement of people (CONRICK; DONOVAN, 2010; PAULSTON; MCLAUGHLIN, 1994).

The collapse of the Soviet Union, the resultant realignment of boundaries in Eastern Europe and Central Asia, along with the expansion of the European Union, have lead to the re-emergence of polities and the emergence of supra-states (de VARENNES, 2012) with new issues of language choice and minority languages creating the need for status planning and the development of language policy. Many of the new situations have lead to difficulties politically and linguistically (See, e.g. KAPLAN; BALDAUF, 2001; SKERRITT, 2012). Economic alliances elsewhere in the world such as ASEAN in Southeast Asia and MERCOSUR (HAMEL, 2003) in Latin America also raise some of these same linguistic issues about what languages will be used for what purposes.

In some polities, there has been an attempt to deconstructing the monolingual ideology and to argue that the presumed costs of multilingualism are outweighed by its benefits. In South Africa, in particular, the declaration of eleven official languages as part of changes to language policy has enhanced the process of democratization there and evidence of this is also available elsewhere (BLOMMAERT, 1996; DEPREZ; DU PLESSIS, 2000), while in Timor-Leste we are seeing an increasing use of vernacular languages (designated as National Languages in the 2002 Constitution) for instruction in primary schools (TAYLOR-LEECH, 2011). Furthermore, Brutt-Griffler (2002) has argued that where multilingualism is well established, world languages like English contribute to additive rather than subtractive bilingualism, although 
this is an issue that Singh, Zhang and Besmel (2012) contests in relation to Afghanistan, China, India and Nepal.

There is a growing realisation that governments may not be suitable as micro language planners in all instances and that some language planning activities must take place at the local level if they are to happen at all (LIDDICOAT; BALDAUF, 2008). The study by Picanço (2012) which reports on a revitalization project conducted in the Kwatá-Laranjal indigenous land in Brazil, illustrates this point. (Also see, CHUA; BALDAUF, 2011.)

Questions of agency and language power are increasingly being examined in a variety of contexts. For example, while language planners in Singapore may be urging Chinese to switch from Chinese 'dialects' to Mandarin or while Malaysian officials may be encouraging everyone to learn the national language Bahasa Malaysia (Malay), in a world where access to languages is more readily available and where there are increasingly strong lingua franca, individuals have greater agency in the languages they learn. Despite strong campaigns to do so, in Singapore many Chinese dialect speakers have chosen not to switch to Mandarin as their heritage language but have instead switched to the dominant national language - English - in their home environment (CHUA; BALDAUF, 2011; KAPLAN; BALDAUF, 2003). Ting (2012) notes that in Sarawak Chinese 'dialect' speakers are moving to Mandarin as it is an alternate standard language and one of ethnic solidarity. These examples illustrate how individual agency - when widespread - may compromise the impact of a national language policy. As a counter example to individual agency, Burke and Oliveira (2012) review the "No Child Left Behind" Act in the United States, and show the exertion of macro top-down policy power may suppress languages other than English, possibly unofficially turning English into the official language in the polity. Finally, Almeida's (2012) study provides us with another reminder of the power that schools have in setting policy and determining what is learned in schools. Although this study focuses on Brazil, the issues are applicable to other polities.

Unlike bilingual education many instances of medium of instruction have been driven by globalisation and internationalization, and this is now a major issue for language-in-education planners. In Bangladesh this has lead to a social and linguistic divide with parallel streams of English and Bangla instruction (HAMID; JAHAN, in press). We see this occurring at the university level in particular where programs of study are being offered in world languages like English to attract international students and to improve local students' English proficiency (ALI; HAMID; MONI, 2011). This is having flow on effects in 
primary education in Asia where there is increasing pressure to begin English earlier, or to offer programs in English (BALDAUF; KAPLAN; KAMWANGAMALU, 2012). As in Malaysia and in other parts of Asia, the issue of norms, what variety of English to teach is raised by Schmitz (2012) more generally and by Vodopija-Krstanoviæ and Brala-Vukanoviæ (2012) in the context of tertiary education in Croatia. In many parts of the world, most users of English will be speaking with other non-native speakers, and this raises the question of whether using some form of ELF (English as a lingua franca) wouldn't be more appropriate - especially for a multiple native-speaking normed language like English - where the question arises, "Which norm should we follow"?

\section{Summary and Conclusions}

In sum, as the overview and the papers found in this volume indicate, language policy and planning is a vibrant disciplinary stream within applied linguistics. The current trends of globalization and internationalization also have their localization counterparts and the tensions between these raise issues of concern for all of us in the field. It is hoped that this brief overview will provide some insights into how the discipline may develop and deal with some of these issues.

\section{Acknowledgement}

I would like to thank the editors, and referees, especially Ricardo Augusto de Souza, for this opportunity to guest edit this issue of Revista Brasileira de Linguística Aplicada, and for their substantial input into the manuscripts found in this volume. In addition I would like to thank my recent $\mathrm{PhD}$ students, whose work I cite here, for the insights their scholarship has given me into the disciplinary interest we share.

\section{References}

AGER, D. E. Prestige and image Planning. In: HINKEL, E. (Ed.). Handbook of Research in Second Language Teaching and Learning. Mahwah, NJ: Lawrence Erlbaum, 2005. p. 1035-1054.

ALI, N.L.; HAMID, M. O; MONI, K. English primary education in Malaysia: policies, outcomes and stakeholders' lived experiences. Current Issues in Language Planning, n. 12, v. 2, p.147-166, 2011. 
ALMEIDA, R. L. T. de. The teaching of English as a foreign language in the context of Brazilian regular schools: A retrospective and prospective view of policies and practices. Revista Brasileira de Linguistica Aplicada, v. 12, n. 2, p. 331-348, 2012. BALDAUF, R. B., Jr. Language planning and policy research: An overview. In: HINKEL, E. (Ed.). Handbook of Research in Second Language Teaching and Learning. Mahwah, NJ: Lawrence Erlbaum, 2005. p. 957-970.

BALDAUF, R. B., Jr. The language situation in American Samoa: Planners, plans and planning. Language Planning Newsletter, n. 8, v. 1, p.1-6, 1982.

BALDAUF, R. B., Jr.; KAPLAN, R. B.; KAMWANGAMALU, N. M.; BRYANT, P. (Ed.). Language Planning in Primary Schools in Asia. New York: Routledge, 2012.

BALDAUF, R. B., Jr.; NGUYEN, T. M. H. Language policy in Asia and the Pacific. In: SPOLSKY, B. (Ed.). The Cambridge Handbook of Language Policy. Cambridge: Cambridge University Press, 2012. p. 617-638.

BLOMMAERT, J. Language planning as a discourse on language and society: The linguistic ideology of a scholarly tradition. Language Problems \& Language Planning, n. 20, p.199-222, 1996.

BRUTT-GRIFFLER, J. World English: A Study in its Development. Clevedon, UK: Multilingual Matters, 2002.

BURKE, A.; OLIVEIRA, L. C. de. Educational policies in the United States and implications for English learners. Revista Brasileira de Linguistica Aplicada, v. 12, n. 2, p. 311-329, 2012.

CHUA, S. K. C.; BALDAUF, R. B., Jr. Micro language planning. In: HINKEL, E. (Ed.). Handbook of Research in Second Language Teaching and Learning. v. 2. New York: Routledge, 2011. p. 936-951.

CONRICK, M.; DONOVAN, P. Immigration and language policy and planning in Québec and Canada: Language learning and integration. Journal of Multilingual and Multicultural Development, n. 31, v. 4, p. 331-345, 2010.

COOPER, R. L. Language Planning and Social Change. Cambridge: Cambridge University Press, 1989.

DEPREZ, K.; du PLESSIS, T. (Ed.). Multilingualism and Government: Belgium, Luxembourg, Switzerland, former Yugoslavia, South Africa. Pretoria, SA: Van Schaik, 2000.

DJITÉ, P. G. Les langues et développement en Afrique. Language Problems \& Language Planning, v. 14, p. 20-32, 1990. 
DUCHÊNE, A.; HELLER, M. Language policy and religion. In: SPOLSKY, B. (Ed.). The Cambridge Handbook of Language Policy. Cambridge: Cambridge University Press, 2012. p. 323-334.

EGGINGTON, W. G. Unplanned language planning. In: KAPLAN, R. B. (Ed.). The Oxford Handbook of Applied Linguistics. $2^{\text {nd }}$ ed. New York: Oxford University Press, 2010. p. 452-462.

FISHMAN, J. A. (Ed.). Advances in Language Planning. The Hague: Mouton, 1974.

FISHMAN, J. A.; FERGUSON, C. A.; DAS GUPTA, J. (Ed.). Language Problems of Developing Nations. New York: Wiley, 1968.

FOX, M. J. Language and Development: A Retrospective Survey of Ford Foundation Language Projects 1952-1974. New York: Ford Foundation, 1975. GAL, S.; IRVINE, J. T. The boundaries of languages and disciplines: How ideologies construct difference. Social Research, n. 62, p. 967-1001, 1995.

GRABE, W.; KAPLAN, R. B. Introduction. In: GRABE, W.; KAPLAN, R. B. (Ed.). Introduction. Introduction to Applied Linguistics. Reading, MA: Addison-Wesley, 1991. p. 1-12.

HAMID, M. O. Globalisation, English for everyone and English teacher capacity: language policy discourses and realities in Bangladesh. Current Issues in Language Planning, n. 11, v. 4, p. 289-310, 2011.

HAMID, M. O.; JAHAN, E. Language, identity and social divides: Medium of instruction debates in the Bangladeshi print media. Applied Linguistics, in press.

HAMEL, R. E. Regional blocks as a barrier against English hegemony? The language policy of Mercosur in South America. In: MAURAIS, J.; MORRIS, M. A. (Ed.). Languages in a Globalising World. Cambridge: Cambridge University Press, 2003.

HAUGEN, E. The implementation of corpus planning: Theory and practice. In: COBARRUBIAS, J.; FISHMAN, J. A. (Ed.). Progress in Language Planning: International Perspectives. Berlin: Mouton de Gruyter, 1983. p. 269-289.

HORNBERGER, N. H. Frameworks and models in language policy and planning. In: RICENTO, T. (Ed.). An Introduction to Language Policy: Theory and Method. Malden, MA: Blackwell, 2006. p. 24-41.

JERRNUDD, B. H.;NEUSTUPNÝ, J. Language planning for whom? In: LAFORGE, L. (Ed.). Proceedings of the International Colloquium on Language Planning. Québec: Les Presses de L’Université Laval, 1987. p. 69-84. 
KAMWANGAMALU, N. M. Language planning: Approaches and methods. In: HINKEL, E. (Ed.). Handbook of Research in Second Language Teaching and Learning. $2^{\text {nd }}$ ed. New York: Routledge, 2011. p. 888-904.

KAMWANGAMALU, N. M. Language policy/language economics interface and mother-tongue education in post-apartheid South Africa. Language Problems \& Language Planning, n. 28, v. 2, p. 131-146, 2004.

KAPLAN, R. B. Whence applied linguistics? In: R. B. KAPLAN (Ed.). The Oxford Handbook of Applied Linguistics, $2^{\text {nd }}$ ed. New York: Oxford University Press, 2010. p. 3-33.

KAPLAN, R. B. CATESOL, Yesterday and today - Tomorrow is left to younger hands. The CATESOL Journal, n. 15, v. 1, p. 7-18, 2003.

KAPLAN, R. B.; BALDAUF, R. B., Jr. Forward to Chinese Language edition. In: Language Planning from Practice to Theory. Beijing: Shangwu Press, in press. KAPLAN, R. B.; BALDAUF, R. B., Jr. Language and Language in Education Planning in the Pacific. Dordrecht: Kluwer Academic, 2003.

KAPLAN, R. B.; BALDAUF, R. B., Jr. Not only English: "English only" and the world. In: GONZALEZ, R. D.; MELIS, I. (Ed.). Language Ideologies: Critical Perspectives on the Official English Movement. v. 2: History, Theory and Politics. Urbana, IL: National Council of Teachers of English, 2001. p. 293-315.

KAPLAN, R. B.; BALDAUF, R. B. Jr. Language Planning from Practice to Theory. Clevedon, UK: Multilingual Matters, 1997.

LI, M. Shaping socialist ideology through language education policy for primary schools in the PRC. Current Issues in Language Planning, n. 12, v. 2, p. 185-204, 2011.

LIDDICOAT, A. J.; BALDAUF, R. B., Jr. Language planning in local contexts: Agents, contexts and interactions. In: LIDDICOAT, A. J.; BALDAUF, R. B., Jr. (Ed.). Language Planning and Policy: Language Planning in Local Contexts. Clevedon, UK: Multilingual Matters, 2008. p. 3-17.

LOW, E-L.; HASHIM, A. English in Southeast Asia: Features, Policy and Language in Use. Amsterdam / Philadelphia: John Benjamins, 2012.

MAKONI, S.; MAKONI, B.; ABDELHAY, A.; MASHIRI, P. Colonial and postcolonial language policies in Africa: Historical and emerging landscapes. In: SPOLSKY, B. (Ed.). The Cambridge Handbook of Language Policy. Cambridge: Cambridge University Press, 2012. p.523-543.

MAURAIS, J.; MORRIS, M. A. (Ed.). Languages in a Globalising World. Cambridge: Cambridge University Press, 2003. 
MAY, S. Language and Minority Rights: Ethnicity, Nationalism and the Politics of Language. New York: Longman, 2001.

MAY, S. Linguistic human rights. In: HINKEL, E. (Ed.). Handbook of Research in Second Language Teaching and Learning. Mahwah, NJ: Erlbaum, 2005. p. 1055-1073.

MOORE, H. "Who will guard the guardians themselves?" National interest versus factional corruption in policymaking for ESL in Australia. In: TOLLEFSON, J. W. (Ed.). Education Policies in Education: Critical Issues. Mahwah, NJ: Lawrence Erlbaum, 2002. p. 111-135.

MÜHLHÄUSLER, P. Language planning and language ecology. Current Issues in Language Planning, n. 1, p. 306-367, 2000.

NEKVAPIL, J. The history and theory of language policy and planning. In: HINKEL, E. (Ed.). Handbook of Research in Second Language Teaching and Learning, $2^{\text {nd }}$ ed. New York: Routledge, 2011. p. 871-887.

NEUSTUPNÝ, J.;NEKVAPIL, J. Language Management in the Czech Republic. Current Issues in Language Planning, n. 4, p. 181-366, 2003.

NEKVAPIL, J.; SHERMAN, T. (Ed.). Language Management in Contact Situations: Perspectives from Three Continents. Frankfurt am Main: Peter Lang, 2009.

PAULSTON, C. B.;McLAUGHLIN, S. Language-in-education planning. In: GRABE, W. et al. (Ed.). Annual Review of Applied Linguistics, n. 14: Foundations of Language Policy and Planning. New York: Cambridge University Press, 1994. p. 53-81.

PAULSTON, C. B.; WATT, J. M. Language policy and religion. In: SPOLSKY, B. (Ed.). The Cambridge Handbook of Language Policy. Cambridge: Cambridge University Press, 2012. p. 335-350.

PENNYCOOK, A. Mother tongue, governmentality and protectionism. International Journal of the Sociology of Language, n. 154, p. 11-28, 2002.

PENNYCOOK, A. English and the Discourses of Colonialism. London / New York: Routledge. 1998.

PHILLIPSON, R. Imperialism and colonialism. In: SPOLSKY, B. (Ed.). The Cambridge Handbook of Language Policy. Cambridge: Cambridge University Press, 2012. p. 203-225.

PHILLIPSON, R. Linguistic Imperialism. Oxford: Oxford University Press, 1982.

PICANÇO, G. Language planning for Mundurukú do Amazonas. Revista Brasileira de Linguistica Aplicada, v. 12, n. 2, p. 405-423, 2012. 
RICENTO, T. Historical and theoretical perspectives in language policy and planning. Journal of Sociolinguistics, n. 4, p. 196-213, 2000.

RUBIN, J.; JERNUDD, B. H. (Ed.). Can Language be Planned? Sociolinguistic Theory and Practice for Developing Nations. Honolulu: University of Hawai' $\mathrm{i}$ Press, 1971.

SILVA, J. F. da; GUNNEWIEK, L. K. Portuguese and Brazilian efforts to spread Portuguese. International Journal of the Sociology of Language, n. 95, p. 71-92, 1992.

SCHMITZ, J. R. “To ELF or not to EFL?” (English as a Lingua Franca): That's the question for Applied Linguistics in a globalized world. Revista Brasileira de Linguistica Aplicada, v. 12, n. 2, p. 249-284, 2012.

SINGH, N. R.; ZHANG, S.; BESMEL, P. Globalization and language policies of multilingual societies: Some case studies of South East Asia. Revista Brasileira de Linguistica Aplicada, v. 12, n. 2, p. 349-380, 2012.

SHOHAMY, E. Language Policy: Hidden Agendas and New Approaches. London / New York: Routledge, 2006.

SHOHAMY, E.; GÖRTER, D. (Ed.). Linguistic Landscape: Expanding the Scenery. London: Routledge, 2009.

SKERRITT, D. M. On discourse, agency and buying eggs: Micro meets macro in Estonian language policy. Future Directions in Applied Linguistics: Local and Global Perspectives.. Newcastle on Tyne: Cambridge Scholars Publishers, 2012. p. 469-507.

SPOLSKY, B. (Ed.) The Cambridge Handbook of Language Policy. Cambridge: Cambridge University Press, 2012a.

SPOLSKY, B. Family language policy - the critical domain. Journal of Multilingual and Multicultural Development, n. 33, v. 1, p. 3-11, 2012b.

SPOLSKY, B.; HULT, F. M. The Handbook of Educational Linguistics. Malden, MA: Blackwell, 2008

TAYLOR-LEECH, K. Timor-Leste: Sustaining and maintaining the national languages in education. Current Issues in Language Planning, n. 12, v. 2, p. 289-308, 2011.

TING, S. H. Variable impact of Malaysia's national language planning on nonMalay speakers in Sarawak. Revista Brasileira de Linguistica Aplicada, v. 12, n. 2, p. 381-403, 2012.

TOLLEFSON, J. W. Critical theory in language policy. In: RICENTO, T. (Ed.). An Introduction to Language Policy: Theory and Method. Malden, MA: Blackwell, 2006. p. $42-59$. 
TOLLEFSON, J. W. Planning language, planning inequality. London: Longman, 1991.

Van ELS, T. Status planning for learning and Teaching. In: HINKEL, E. (Ed.). Handbook of Research in Second Language Teaching and Learning. v. 1. Mahwah, NJ: Lawrence Erlbaum, 2005. p. 971-991.

VARENNES, F. de. Language policy at the supranational level. In: SPOLSKY, B. (Ed.). The Cambridge Handbook of Language Policy. Cambridge: Cambridge University Press, 2012. p. 149-173.

VODOPIJI-KRSTANOVIÆ, I.; BTALA-VUKANOVIÆ, M. EFL students perspectives on English: The (widening) gap between ideals and practices. Revista Brasileira de Linguistica Aplicada, v. 12, n. 2, p. 285-309, 2012.

WILLIAMS, G. Sociolinguistics: A Sociolinguistic Critique. London, Routledge, 1992.

WHITELEY, W. H. (Ed.). Language in Kenya. Nairobi: Oxford University Press, 1974.

WRIGHT, S. Language policy, the nation and nationalism. In: SPOLSKY, B. (Ed.). The Cambridge Handbook of Language Policy. Cambridge: Cambridge University Press, 2012. p.59-78.

ZHAO, S. Actors in language planning. In: HINKEL, E. (Ed.). Handbook of Research in Second Language Teaching and Learning. v. 2. New York: Routledge, 2011. p. 905-923.

ZHAO, S.; BALDAUF, R. B., Jr. Individual agency in language planning: Chinese Script reform as a case study. Language Problems \& Language Planning, n. 36, v. 1, p. 1-24, 2012. 


\section{APPENDIX A: A Framework for Language Planning Goals (KAPLAN; BALDAUF, 2003, p.202)}

\begin{tabular}{|c|c|c|}
\hline $\begin{array}{l}\text { Approaches } \\
\text { Types (overt-covert) }\end{array}$ & \begin{tabular}{|l|} 
1. Policy Planning \\
(on form) \\
Goals \\
\end{tabular} & $\begin{array}{l}\text { 2. Cultivation Planning } \\
\text { (on function) } \\
\text { Goals } \\
\end{array}$ \\
\hline $\begin{array}{l}\text { 1. Status Planning } \\
\text { (about society) }\end{array}$ & $\begin{array}{l}\text { Status Standardisation } \\
\cdot \text { Officialisation } \\
\cdot \text { Nationalisation } \\
\cdot \text { Proscription }\end{array}$ & $\begin{array}{l}\text { Status Planning } \\
\text { Revival } \\
\text { - Restoration } \\
\text { - Revitalisation } \\
\text { - Reversal } \\
\text { Maintenance } \\
\text { Interlingual Communication } \\
\text { - International } \\
\text { - Intra-national } \\
\text { Spread }\end{array}$ \\
\hline $\begin{array}{l}\text { 2. Corpus Planning } \\
\text { (about language) }\end{array}$ & $\begin{array}{l}\text { Standardisation } \\
\text { Corpus } \\
\text { - Graphisation } \\
\text { - Grammatication } \\
\text { - Lexication } \\
\text { Auxiliary Code } \\
\text { - Graphisation } \\
\text { - Grammatication } \\
\text { - Lexication }\end{array}$ & $\begin{array}{l}\text { Corpus Elaboration } \\
\text { Lexical Modernisation } \\
\text { Stylistic Modernisation } \\
\text { Renovation } \\
\text { - Purification } \\
\text { - Reform } \\
\text { - Stylistic simplification } \\
\text {. Terminological unification } \\
\text { Internationalisation }\end{array}$ \\
\hline $\begin{array}{l}\text { 3. Language-in-Education } \\
\text { Planning } \\
\text { (about learning) }\end{array}$ & $\begin{array}{l}\text { Policy Development } \\
\text { Access Policy } \\
\text { Personnel Policy } \\
\text { Curriculum Policy } \\
\text { Methods \& Materials Policy } \\
\text { Resourcing Policy } \\
\text { Community Policy } \\
\text { Evaluation Policy }\end{array}$ & $\begin{array}{l}\text { Acquisition Planning } \\
\text { Reacquisition } \\
\text { Maintenance } \\
\text { Foreign / Second Language } \\
\text { Shift }\end{array}$ \\
\hline $\begin{array}{l}\text { 4. Prestige Planning } \\
\text { (about image) }\end{array}$ & $\begin{array}{l}\text { Language Promotion } \\
\text { - Official/Government } \\
\text { - Institutional } \\
\text { - Pressure group } \\
\text { - Individual }\end{array}$ & $\begin{array}{l}\text { Intellectualisation } \\
\cdot \text { Language of Science } \\
\cdot \text { Language of Professions } \\
\cdot \text { Language of High Culture }\end{array}$ \\
\hline
\end{tabular}

